\title{
The Impact of Sleeping Duration on the Risk of Breast Cancer: A systematic review and meta- analysis of population-based cohort studies
}

Amos Ochieng Okutse, College of Pure and Applied Sciences; Jomo Kenyatta University of Agriculture and Technology, Kenya

\section{Abstract}

The impact of different sleeping categories on the risk of breast cancer has remained debatable. This paper sought to systematically synthesise the available literature on this relationship from population-based cohort studies using meta-analytic procedures.

Studies about sleep duration and breast cancer were identified from the Cochrane Library database, EMBASE and PubMed databases for papers published up to February 2019.

Identified studies were analysed for quality using the Newcastle-Ottawa Scale. Effect sizes were visualised using funnel plots. Study heterogeneity was quantified using $\mathrm{I}^{2}$ and visualised using Baujat plots. Publication prejudice was evaluated using Eggers regression model, with visualisations using funnel plots.

Eight cohort studies met the inclusion criteria. Random-effects model revealed nonstatistically significant evidence of an association between short or long sleep and breast cancer Odds Ratio $(\mathrm{OR})=0.90 ;(95 \%$ CI $0.79-1.02)$ and $\mathrm{OR}=0.95(0.88-1.02)$ respectively. There was moderate to high heterogeneity $\mathrm{I}^{2}(95 \% \mathrm{CI})=74.40 \%$ (48.2087.40\%) among studies examining short sleep and breast cancer, and low to moderate heterogeneity in studies for long sleep and breast cancer $\mathrm{I}^{2}(95 \% \mathrm{CI})=3.0 \%(0.00-$ $68.60 \%)$.

This study found non-substantial evidence of associations between sleeping periods and breast cancer in women. Studies employing novel sleep-measurement methodologies should be carried out to examine the underlying relationship. 
Keywords: Breast cancer; sleep duration and breast cancer; systematic review; metaanalysis of breast cancer studies; population-based cohort studies.

\section{Introduction}

Globally, the burden of site-specific cancers has increased based on published global estimates (Bray et al., 2018). While most countries have implemented measures to reduce the effects of cancer - such as the implementation of national policies like the National Cancer Control Strategy in Kenya (Topazian et al., 2016) and the development of early detection and mammographic screening centres (Yip et al., 2008) - the disease still remains a significant cause of death with its burden expected to increase due to ageing, population growths and changing life regimens such as cigarette smoking, alcohol drinking and general body dormancy (Sanchis-Gomar et al., 2015; Jung et al., 2016). Breast tumours have remained a domineering cause of demise in the female population. In the USA alone, the rate of invasive breast cancer is approximated at 232,340 cases, with one in every eight US women anticipated to develop breast cancer during the course of her life (Ma and Jemal, 2013). Belgium and Luxembourg had the highest age-standardised rates of breast cancer in 2018 (113.2 and 109.3 per 100, 000 respectively) based on estimates from the American Institute for Cancer Research.

The underlying relationship between sleeping patterns and all cancers has been examined in depth elsewhere in case-control studies (Wang et al., 2015, 2016; Gu et al., 2016). Whereas sufficient sleep is necessary for healthy development, insufficient sleep has been previously linked with an increased incidence of cancer of the breast as a result of possible suppression of melatonin production (Stevens, 2005).

Previous studies have linked insufficient sleep $(<7 \mathrm{~h})$ to obesity, possible metabolic dysfunctions and chronic inflammations. (Gangwisch et al., 2007; Irwin et al., 2008). Sleeping patterns appear to be changing. In previous studies, the number of individuals who sleep for short durations of time has been reported to increase whereas the number of individuals who sleep for long durations of time $(9+\mathrm{h}$ of sleep per night) has been reported to decrease considerably (Jean-Louis et al., 2014). Previous literature on the influence of sleep on cancer has found evidence ranging from positive (Jiao et al., 2013; Luojus et al., 2014) to inverse (Markt et al., 2016; Heckman et al., 2017) and null associations (Cohen et al., 2015; Hurley et al., 2015). 
While there exists ample literature on these relationships, as presented above, there exist no records that explicitly and systematically review, synthesise and evaluate the available research on the effect of both long and short sleeping patterns on the risk of breast cancer in both pre- and post-menopausal women of different ethnicities, a factor that is important in understanding variations in incidence by race. Moreover, the fund of knowledge concerning dose-response relationships of the various studies using self-reported sleeping categories from population-based cohort studies is deficient. Also, relations between sleeping patterns and breast tumours from analyses previously conducted is obscure (Markt et al., 2016; Heckman et al., 2017).

This systematic review and meta-analysis aimed to systematically evaluate existing literature and update the fund of knowledge on the relationship between both long and short sleep patterns on the risk of breast cancer using multi-ethnic populationbased cohort studies. We also aimed to explore the relationships performing subgroup analyses for publication biases and study heterogeneity.

\section{Methodology}

This systematic review and meta-analysis was conducted in accord with the 'Preferred Reporting Items for Systematic Reviews and Meta-Analyses' (PRISMA; Shamseer et al., 2015).

\section{Data sources}

Studies were expansively and intensively identified through searches in the academic journal databases Cochrane Library database, PubMed and EMBASE, and they included studies up to February 2019 that evaluated the relationship between the duration of sleep and the risk of acquiring breast cancer. Study identification and extraction involved use of keywords including 'sleep' or 'sleep duration' and 'tumor' or 'cancer' or 'breast cancer'. Additional pertinent cohort studies were acquired through scanning the bibliographies of studies previously identified.

\section{Study selection and eligibility criteria}

Studies were initially screened for relevance using their abstracts and titles. Those studies that bore potential of inclusion into the review were identified and their full versions obtained. Inclusion of articles was based on their novelty, cohort studies, or because the paper explicitly provided estimates for calculation of Odds Ratio (OR) and 
95\% Confidence Intervals (CI). Studies were included that allowed calculation of these estimates through their literature, were published in English and were based on adult populations. On the other hand, review articles, case-control studies, studies with duplicated data, that did not provide estimates for OR and CI, were clinical trials, cellrelated or did not mention breast tumours were excluded.

\section{Data extraction}

Spreadsheets which were designed in MS Excel specifically for this study. Where papers met the inclusion criteria, their details were checked and entered into the spreadsheet. For all included studies, details of the authors, year of publication, the country where the studies were conducted, types of cancers reported and the number of cancer cases reported at the end of the evaluation period were extracted (see Table 1). Also, the sample sizes and published estimates (Relative Risk (RR), Odds Ratio (OR), Hazard Ratio (HR) and 95\% CI), including the author conclusions, were obtained. Unadjusted Odds Ratios were calculated using the published study estimates. The number of events in the experimental group (Ee), the total number of persons in the experimental group ( $\mathrm{Ne}$ ) and the number of events and total individuals in the reference group (Ec and Nc respectively) were extracted for analyses.

\begin{tabular}{|c|c|c|c|c|c|c|c|c|}
\hline $\begin{array}{l}\text { Author, year, } \\
\text { Country/area }\end{array}$ & $\begin{array}{l}\text { Study } \\
\text { design }\end{array}$ & $\begin{array}{c}\text { Types } \\
\text { of } \\
\text { cancers }\end{array}$ & $\begin{array}{l}\text { No. } \\
\text { of } \\
\text { cases }\end{array}$ & $\begin{array}{l}\text { Sample } \\
\text { sizes }(n)\end{array}$ & $\begin{array}{c}\text { Sleep } \\
\text { Duration }\end{array}$ & $\begin{array}{c}\text { Adjusted } \\
\text { OR/RR/HR(95\%Cl) }\end{array}$ & $\begin{array}{c}\text { Author } \\
\text { Conclusions }\end{array}$ & $\begin{array}{l}\text { NOS Score \& } \\
\text { Comments }\end{array}$ \\
\hline $\begin{array}{l}\text { Gu et al., } \\
2016, \text { USA }\end{array}$ & $\begin{array}{l}\text { Cohort } \\
\text { study }\end{array}$ & $\begin{array}{l}\text { Breast } \\
\text { cancer }\end{array}$ & 5919 & 123858 & $\begin{array}{l}<55-6 \\
7-8 \geq 9\end{array}$ & $\begin{array}{l}0.84(0.71-0.98) \\
1.00(0.94-1.05) \\
1.000 .89(0.77- \\
1.03)\end{array}$ & $\begin{array}{l}\text { 'In conclusion, we } \\
\text { observed } \\
\text { potential } \\
\text { increased risks of } \\
\text { several cancer } \\
\text { sites among men } \\
\text { of short sleep } \\
\text { duration, and } \\
\text { changed risks of } \\
\text { several cancer } \\
\text { sites in women of } \\
\text { both short and } \\
\text { long sleep } \\
\text { duration in older } \\
\text { population. Only } \\
\text { the association of } \\
\text { stomach cancer } \\
\text { achieved overall } \\
\text { statistical } \\
\text { significance and } \\
\text { no association } \\
\text { survives multiple } \\
\text { comparison } \\
\text { adjustment. } \\
\text { Further studies } \\
\text { are warranted to } \\
\text { replicate these } \\
\text { findings.' }\end{array}$ & $\begin{array}{l}\text { - The sample was } \\
\text { representative } \\
\text { (2). } \\
\text { - The study } \\
\text { allowed } \\
\text { ascertainment } \\
\text { and } \\
\text { comparability of } \\
\text { exposure (2). } \\
\text { - The study } \\
\text { provided enough } \\
\text { time for relevant } \\
\text { outcomes to } \\
\text { occur (3). }\end{array}$ \\
\hline
\end{tabular}


Reinvention: an International Journal of Undergraduate Researç 13:1 (2020)

\begin{tabular}{|c|c|c|c|c|c|c|c|c|}
\hline $\begin{array}{l}\text { Hurley et al., } \\
\text { 2015, USA }\end{array}$ & $\begin{array}{l}\text { Cohort } \\
\text { study }\end{array}$ & $\begin{array}{l}\text { Breast } \\
\text { cancer }\end{array}$ & 4381 & 101609 & $\begin{array}{l}3-67-9 \\
\geq 10\end{array}$ & $\begin{array}{l}0.98(0.92-1.05) \\
1.001 .25(0.93- \\
1.68)\end{array}$ & $\begin{array}{l}\text { 'These analyses } \\
\text { suggest that } \\
\text { longer sleep may } \\
\text { be associated } \\
\text { with increased } \\
\text { risks of estrogen- } \\
\text { mediated cancers. } \\
\text { Further studies } \\
\text { with more refined } \\
\text { measures of sleep } \\
\text { duration and } \\
\text { quality are } \\
\text { warranted.' }\end{array}$ & $\begin{array}{l}\text { - } 6 \\
\text { The sample was } \\
\text { representative } \\
\text { (2). } \\
\text { - The study } \\
\text { allowed } \\
\text { ascertainment } \\
\text { and } \\
\text { comparability of } \\
\text { exposure (2) } \\
\text { The study } \\
\text { provided enough } \\
\text { time for relevant } \\
\text { outcomes to } \\
\text { occur (2). }\end{array}$ \\
\hline $\begin{array}{l}\text { Qian et al., } \\
\text { 2015, USA }\end{array}$ & $\begin{array}{l}\text { Cohort } \\
\text { study }\end{array}$ & $\begin{array}{l}\text { Breast } \\
\text { cancer }\end{array}$ & 1553 & 40013 & $\begin{array}{l}<66-<7 \\
7-<88- \\
<9 \geq 9\end{array}$ & $\begin{array}{l}0.87(0.64-1.18) \\
1.04(0.90-1.20) \\
0.93(0.82-1.05) \\
1.001 .00(0.84- \\
1.19)\end{array}$ & $\begin{array}{l}\text { 'Our finding does } \\
\text { not support an } \\
\text { association } \\
\text { between sleep } \\
\text { duration and } \\
\text { overall breast } \\
\text { cancer risk. } \\
\text { However, the } \\
\text { effect of sleep on } \\
\text { different } \\
\text { subtypes of } \\
\text { breast cancer } \\
\text { deserves further } \\
\text { investigation.' }\end{array}$ & $\begin{array}{l}8 \\
\text { - The sample was } \\
\text { representative } \\
\text { (4). } \\
\text { - The study } \\
\text { allowed } \\
\text { ascertainment } \\
\text { and } \\
\text { comparability of } \\
\text { exposure (2). } \\
\text { The study } \\
\text { allowed enough } \\
\text { time for } \\
\text { outcomes to } \\
\text { occur (2). }\end{array}$ \\
\hline
\end{tabular}

\begin{tabular}{|c|c|c|c|c|c|c|c|c|c|}
\hline $\begin{array}{l}\text { Wu et al., } \\
2008, \\
\text { Singapore }\end{array}$ & $\begin{array}{l}\text { Cohort } \\
\text { study }\end{array}$ & $\begin{array}{l}\text { Breast } \\
\text { cancer }\end{array}$ & 525 & 33528 & $\leq 678 \geq 9$ & $\begin{array}{l}1.001 .03(0.8-1.3) \\
0.90(0.7-1.1) 0.81 \\
(0.6-1.2)\end{array}$ & $\begin{array}{l}\text { 'Sleep duration } \\
\text { may influence } \\
\text { breast cancer } \\
\text { risk, possibly via } \\
\text { its effect on } \\
\text { melatonin levels.' }\end{array}$ & $\begin{array}{l}8 \\
\bullet \\
\bullet\end{array}$ & $\begin{array}{l}\text { The sample was } \\
\text { representative } \\
\text { (4). } \\
\text { The study } \\
\text { allowed } \\
\text { ascertainment } \\
\text { and } \\
\text { comparability of } \\
\text { exposure (2). } \\
\text { The study } \\
\text { provided relevant } \\
\text { outcomes (2). }\end{array}$ \\
\hline
\end{tabular}

\begin{tabular}{|c|c|c|c|c|c|c|c|c|}
\hline $\begin{array}{l}\text { Vogtmann et } \\
\text { al., 2013, } \\
\text { USA }\end{array}$ & $\begin{array}{l}\text { Cohort } \\
\text { study }\end{array}$ & $\begin{array}{l}\text { Breast } \\
\text { cancer }\end{array}$ & 5149 & 110011 & $\begin{array}{l}\leq 5678 \\
\geq 9\end{array}$ & $\begin{array}{l}0.95(0.85-1.07) \\
0.94(0.87-1.00) \\
1.000 .99(0.92- \\
1.06) 1.03(0.90- \\
1.18)\end{array}$ & $\begin{array}{l}\text { 'In conclusion, } \\
\text { this large study } \\
\text { from the WHI } \\
\text { does not provide } \\
\text { support for an } \\
\text { association } \\
\text { between self- } \\
\text { reported sleep } \\
\text { duration, sleep } \\
\text { quality, insomnia } \\
\text { or sleep } \\
\text { disturbance with } \\
\text { the risk of breast }\end{array}$ & $\begin{array}{l}8 \\
\text { - The sample was } \\
\text { representative } \\
\text { (4). } \\
\text { - The study } \\
\text { allowed } \\
\text { ascertainment } \\
\text { and } \\
\text { comparability of } \\
\text { exposure (2). } \\
\text { - The study }\end{array}$ \\
\hline
\end{tabular}




\begin{tabular}{|c|c|c|c|c|c|c|c|c|}
\hline & & & & & & & $\begin{array}{l}\text { cancer in } \\
\text { postmenopausal } \\
\text { women. The } \\
\text { observed } \\
\text { association } \\
\text { between } \\
\text { insomnia and the } \\
\text { risk of breast } \\
\text { cancer among } \\
\text { women who do } \\
\text { not use sleep } \\
\text { aides warrants } \\
\text { further } \\
\text { investigation. } \\
\text { Consideration of } \\
\text { the association } \\
\text { between sleep } \\
\text { measures and } \\
\text { different breast } \\
\text { cancer subtypes } \\
\text { could also be } \\
\text { considered.' }\end{array}$ & $\begin{array}{l}\text { allowed enough } \\
\text { time for } \\
\text { outcomes to } \\
\text { occur (2). }\end{array}$ \\
\hline $\begin{array}{l}\text { Kakizaki et } \\
\text { al., 2008, } \\
\text { Japan }\end{array}$ & $\begin{array}{l}\text { Cohort } \\
\text { study }\end{array}$ & $\begin{array}{l}\text { Breast } \\
\text { cancer }\end{array}$ & 143 & 28515 & $\leq 678 \geq 9$ & $\begin{array}{l}1.67(1.00-2.78) \\
1.000 .99(0.59- \\
1.65) 0.29(0.09- \\
0.98)\end{array}$ & $\begin{array}{l}\text { 'In conclusion, we } \\
\text { have found a } \\
\text { significant inverse } \\
\text { association } \\
\text { between sleep } \\
\text { duration and } \\
\text { breast cancer risk } \\
\text { in Japanese } \\
\text { women, those } \\
\text { who slept } 6 \text { h or } \\
\text { less having a } \\
\text { significantly } \\
\text { increased risk.' }\end{array}$ & $\begin{array}{l}8 \\
\text { - The sample was } \\
\text { representative } \\
\text { (4). } \\
\text { - The study } \\
\text { allowed } \\
\text { ascertainment } \\
\text { and } \\
\text { comparability of } \\
\text { exposure (2). } \\
\text { - The study } \\
\text { allowed enough } \\
\text { time for } \\
\text { outcomes to } \\
\text { occur (2). }\end{array}$ \\
\hline $\begin{array}{l}\text { Pinheiro et } \\
\text { al., 2006, } \\
\text { USA }\end{array}$ & $\begin{array}{l}\text { Cohort } \\
\text { study }\end{array}$ & $\begin{array}{l}\text { Breast } \\
\text { cancer }\end{array}$ & 4223 & 77418 & $\begin{array}{l}\leq 5678 \\
\geq 9\end{array}$ & $\begin{array}{l}0.93(0.79-1.09) \\
0.98(0.91-1.06) \\
1.001 .05(0.97- \\
1.13) 0.95(0.82- \\
1.11)\end{array}$ & $\begin{array}{l}\text { 'In this } \\
\text { prospective study, } \\
\text { we found no } \\
\text { convincing } \\
\text { evidence for an } \\
\text { association } \\
\text { between sleep } \\
\text { duration and the } \\
\text { incidence of } \\
\text { breast cancer.' }\end{array}$ & $\begin{array}{l}6 \\
\text { - The sample was } \\
\text { representative } \\
\text { (2). } \\
\text { - The study } \\
\text { allowed } \\
\text { ascertainment } \\
\text { and } \\
\text { comparability of } \\
\text { exposure (2). } \\
\text { - The study } \\
\text { allowed enough } \\
\text { time for } \\
\text { outcomes to } \\
\text { occur (2). }\end{array}$ \\
\hline $\begin{array}{l}\text { Verkasalo et } \\
\text { al., 2005, } \\
\text { Finland }\end{array}$ & $\begin{array}{l}\text { Cohort } \\
\text { study }\end{array}$ & $\begin{array}{l}\text { Breast } \\
\text { cancer }\end{array}$ & 242 & 12222 & $\begin{array}{l}\leq 67-8 \\
\geq 9\end{array}$ & $\begin{array}{l}0.85(0.54-1.34) \\
1.000 .69(0.45- \\
1.06)\end{array}$ & $\begin{array}{l}\text { 'This study } \\
\text { provides some } \\
\text { support for a } \\
\text { decreased risk of } \\
\text { breast cancer in } \\
\text { long sleepers.' }\end{array}$ & $\begin{array}{l}8 \\
\text { - The sample was } \\
\text { representative(4). } \\
\text { - The study } \\
\text { allowed } \\
\text { ascertainment } \\
\text { and }\end{array}$ \\
\hline
\end{tabular}


Table 1: Characteristics of the included cohort studies

\section{Study quality assessment}

A quality assessment was carried out using the Newcastle-Ottawa Scale (NOS; Stang, 2010). The evaluation was based on (i) participant selection, (ii) comparability and (iii) outcomes, with studies being assigned scores $0-9$. Studies with scores $\geq 7$ were deemed to be of high quality (Table 2).

\begin{tabular}{|c|c|c|c|c|c|c|c|c|c|}
\hline Study ID & Study & Year & $\mathrm{Ee}$ & $\mathrm{Ne}$ & Ec & Nc & Sleep Duration & Study Type & Study Quality* \\
\hline 1 & Verkasalo et al. & 2015 & 23 & 1181 & 188 & 9053 & short & cohort & 8 \\
\hline 2 & Vogtmann et al. & 2013 & 355 & 8686 & 2049 & 41970 & short & cohort & 8 \\
\hline 3 & Qian et al. & 2015 & 45 & 1634 & 631 & 16032 & short & cohort & 8 \\
\hline 4 & Pinheiro et al. & 2009 & 174 & 3553 & 1752 & 32041 & short & cohort & 6 \\
\hline 5 & Kakizaki et al. & 2008 & 42 & 4549 & 40 & 7087 & short & cohort & 8 \\
\hline 6 & Wu et al. & 2008 & 179 & 11370 & 131 & 8835 & short & cohort & 8 \\
\hline 7 & Hurley et al. & 2015 & 1303 & 26440 & 3699 & 74211 & short & cohort & 6 \\
\hline 8 & Guet al. & 2016 & 162 & 4441 & 3648 & 74200 & short & cohort & 7 \\
\hline 9 & Verkasalo et al., & 2015 & 31 & 1988 & 188 & 9053 & long & cohort & 8 \\
\hline 10 & Vogtmann et al., & 2013 & 235 & 4693 & 2049 & 41970 & long & cohort & 8 \\
\hline 11 & Qian et al., & 2015 & 161 & 4104 & 631 & 16032 & long & cohort & 8 \\
\hline 12 & Pinheiro et al., & 2009 & 189 & 3657 & 1752 & 32041 & long & cohort & 6 \\
\hline 13 & Kakizaki et al., & 2008 & 11 & 3692 & 40 & 7087 & long & cohort & 8 \\
\hline 14 & Wu et al., & 2008 & 29 & 2284 & 131 & 8835 & long & cohort & 8 \\
\hline 15 & Hurley et al., & 2015 & 51 & 958 & 3699 & 74211 & long & cohort & 6 \\
\hline 16 & Guet al., & 2016 & 189 & 4194 & 3648 & 74200 & long & cohort & 7 \\
\hline
\end{tabular}

*study quality was assessed by the NOS Scale. " study ID 1 to 8 assess short sleep and breast cancer whereas study ID 8 to 16 assess the impact of long sleep duration on breast cancer.

Table 2: Meta-analyses data and study quality assessment

\section{Statistical data analysis}


Meta-analytical procedures were carried out using the inverse variance method and DerSimonian-Laird Estimator for tau ${ }^{2}$. Both fixed- and random-effects models were used in pooling the risk estimates from individual studies. The extracted associations from each study were used in evaluating the relationship between the risk of breast cancer and the extent of sleep (RR, HR and OR 95\% CI). These estimates were deemed equivalent to each other due to the rareness of breast cancer as an outcome (Shamseer et al., 2015).

The assessment of the duration of sleep was carried out based on how each study reported their findings. Sleep durations were categorised as either short, medium or long. Each study denoted sleep categories as follows: short sleeping category $<5 \mathrm{~h}$ or $\leq 5 \mathrm{~h}$ (Pinheiro et al., 2006; Vogtmann et al., 2013; Gu et al., 2016), 3-6 h (Hurley et al., 2015), <6h or $\leq 6 \mathrm{~h}$ (Verkasalo et al., 2005; Kakisaki et al., 2008; Wu et al., 2008; Qian et al., 2015). Long sleeping durations were defined as $\geq 9 \mathrm{~h}$ (Verkasalo et al., 2005; Pinheiro et al., 2006; Kakisaki et al., 2008; Wu et al., 2008; Vogtmann et al., 2013; Qian et al., 2015; Gu et al., 2016) or $\geq 10 \mathrm{~h}$ (Hurley et al., 2015).

The OR for each included study were calculated and 95\% CIs estimated for both short and long sleepers in comparison to the reference category. A standard reference category of $7 \mathrm{~h}$ of sleep per night was employed to allow uniformity, comparability and to reduce biases.

Between study, heterogeneity was guesstimated using the $\mathrm{Q}$ test (conveyed with a pvalue) and quantified using $\mathrm{I}^{2}$ statistic. The $\mathrm{Q}$-statistic was used to assess the null hypothesis that all the studies included in the analysis are investigating a similar effect. A statistically significant Q-statistic was suggestive of a non-similar effect size among the studies (Quintana, 2015). In quantifying heterogeneity, $\mathrm{I}^{2}$ values from $25 \%$, $50 \%$ and $75 \%$ were viewed as evidence of low, modest and high heterogeneity respectively (Quintana, 2015).

Sub-group analyses were performed by sleep duration as either short or long sleep duration against the developed standard reference category (7h). Funnel plots and Baujat plots were used to inspect the included studies for possibilities of publication bias and each studies contribution to overall heterogeneity respectively. Eggers regression was used to test for publication bias (Egger et al., 1997). Forest plots were used to visually present the pooled effects of the studies end to end with the calculated summary effect sizes (Quintana, 2015). All analytical procedures used R programming environment, version 3.6.0, and employed the R Package 'Meta' 
(Schwarzer et al., 2015). P-values smaller than 0.05 were deemed statistically significant.

\section{Results}

\section{Search results and selection}

Database searches identified 5288 records with 3418 from EMBASE, 1321 from PubMed and 549 articles from the Cochrane Library (see Figure 1). Article screening excluded a total of 4236 articles from the analysis since they were either reviews, meta-analyses, reports or showed obvious irrelevance. From the remainder, 95 articles were then screened and 70 articles were subsequently excluded since they did not provide relevant data. The 25 remaining articles were further evaluated based on the inclusion and exclusion criteria to remain with eight population-based cohort studies after exclusion of ten articles with no mention of breast cancer and four case-control studies (excluded because they do not clearly indicate the temporal sequence between exposure and outcome). 

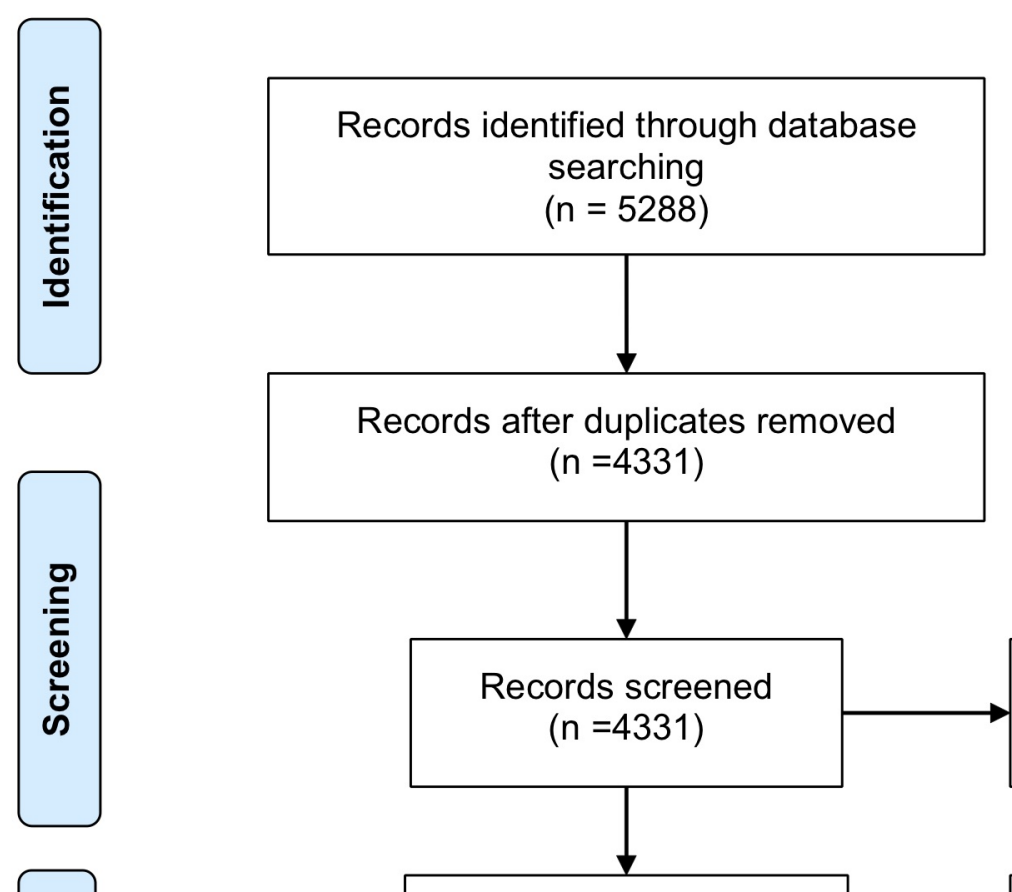

Records excluded $(n=4236)$
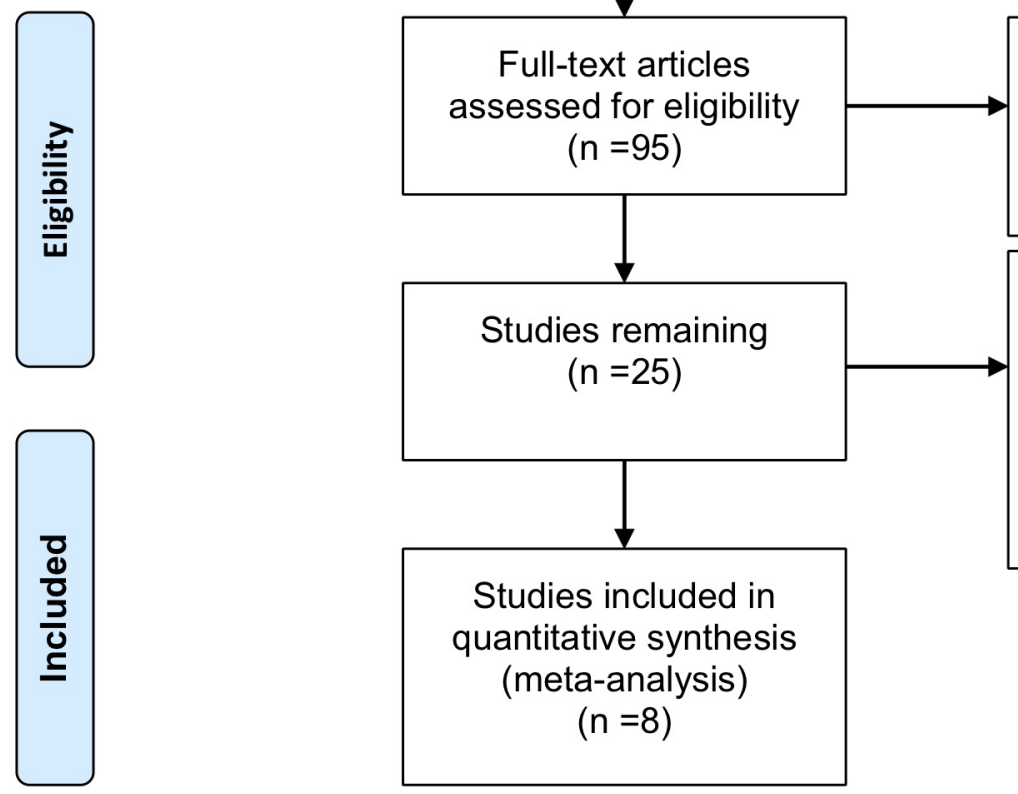

Full-text articles excluded, with reasons $\mathrm{n}=70$

Other articles excluded No mention of breast cancer $(n=10)$ Case control studies $(n=4)$ No estimates $(n=3)$

Figure 1: PRISMA Flow Diagram for the included studies. The flow diagram indicates the number of studies included in the meta-analysis at each stage. Adapted from: Moher et al., 2009).

\section{Description of the included studies}

Verkasalo et al. (2005) sought to determine whether long sleep patterns are linked to decreases in the danger of developing breast cancer and relations of cancer with inadequate sleep or lack thereof coupled up with poor sleep quality. The authors hypothesised that there would be an indirect relationship between the risk of breast 

cancer and the sleeping duration of the study population, possibly explained by the significant increases in the overall melatonin production in the long sleeping study participants. Using a self-administered questionnaire, the authors used the Finnish population-based cohort study of females born before the year 1958. Restricting the analysis to 7396 females with stable sleeping patterns in 1975 and 1981, the study showed there were 146 breast cancer cases with Hazard Ratios of 1.10 (95\% CI 0.592.05), 1.0 and 0.28 (95\% CI 0.09-0.88). The authors concluded that participants who slept for longer periods had a slightly reduced risk of acquiring breast cancer.

Vogtmann et al. (2013) sought to examine whether sleep duration, quality of sleep, sleep disturbances and insomnia had any significant association with breast cancer rate in the 'Women's Health Initiative(WHI)'. The study enrolled 110,011 women from the ages of 50 to 79 with no prior cancer history. The participants' sleep quality, duration and other individual-reported measures of sleeping were assessed over four weeks. After follow-up, 5149 breast-cancer incidents were recorded. Slightly adjusted sleep models for the three sleeping categories - using 7 h sleep per night as the reference group, $\leq 5 \mathrm{~h}$ (HR 0.89;95\% CI:0.80-1.00) or 6h of sleep per night (HR 0.92; 95\% CI:0.85-0.98) - revealed a substantial inverse relationship between breast-cancer and the sleeping categories $\left(\mathrm{P}_{\text {trend }}=0.00\right)$. Vogtmann et al. concluded that the study did not provide substantial evidence of an association between sleep and breast-cancer incidence among the study participants.

Qian et al. (2015) inspected the relationship between the duration of sleep and the risk of development of breast cancer based on estrogen receptor (ER) and progesterone receptor (PR) status. From the 40,013 females in the Breast Cancer Demonstration Project from which there were 1846 breast-cancer cases, the authors examined selfreported sleep patterns and duration during the week and on weekends in relation to breast-cancer incidence. Cox regression algorithms were utilised in guesstimating the RR and the corresponding confidence limits. While the authors found no significant statistical links between sleeping intervals and the inclusive risk of breast cancer, shorter sleeping patterns or behaviours were statistically significantly associated with decreased risk of breast cancer using 8-9h of sleep per night as the reference group and <6h of sleep per night as the short sleeping group RR (95\% CI) $=0.54$ (0.31 to 0.93; $\left.P_{\text {trend }}=0.00\right)$. Qian et al. concluded that the study did not provide evidence of an association between breast cancer and the patterns and duration of sleep, suggesting further investigation of the overall effect of sleep on breast-cancer sub-types. 
Pinheiro et al., (2006) aimed to determine whether sleep duration might have an effect on the danger of acquiring breast cancer using the 'Nurses' Health Study', a cohort study in which individuals were followed prospectively. The authors explored the connotation between reported sleep duration patterns from the year 1986 and the succeeding risk of cancer of the breast after follow-up. Of the 77,418 females studied in the cohort, 4223 incident cases of breast cancer were reported. Using women who slept $7 \mathrm{~h}$ per night as the reference group, covariate-adjusted Hazard Ratios obtained from cox regression models for the women sleeping 5, 6, 8 and 9 hours were $\mathrm{HR}=0.93$; 95\%CI (0.79 to 1.09$), \mathrm{HR}=0.98 ;(0.91-1.06), \mathrm{HR}=1.05 ;(0.97$ to 1.13$)$ and $\mathrm{HR}=0.95 ;(0.82$ to 1.11) correspondingly. The authors found no substantial suggestions of a relationship amid the duration of sleep and the risk of developing breast cancer.

Kakizaki et al. (2008) examined the connotation between the length of sleep and the risk of breast-cancer development in a female populace from the Miyagi Prefecture in north-eastern Japan. The study found reverse associations between breast cancer and the duration of sleep using women who slept for $7 \mathrm{~h}$ per night as the reference group. HRs (95\% CI) of women who slept for $\leq 6 \mathrm{~h}, 8 \mathrm{~h}$, and $\geq 9 \mathrm{~h}$ were 1.62 (1.05-2.50), 1.14 (0.36-1.43), and $0.72(0.36-1.43)$ respectively $\left(\mathrm{P}_{\text {trend }}=0.03\right)$. Kakisaki et al. found no statistically important links between cancer of the breast and possible confounders.

Wu et al. (2008) investigated the relations of 'self-reported' measures of duration of sleep and the ensuing risk of breast cancer after follow-up using the Singapore Chinese Study (a cohort study). After an 11-year constant follow-up, 525 incident cases of breast cancer were identified from 33,528 women. Wu et al. found that sleep duration statistically significantly increased with decreasing risk of cancer of the breast among the post-menopausal females at baseline $\left(\mathrm{P}_{\text {trend }}=0.05\right)$. Of the participants who reported $9+$ h of sleep per night, the reported RR was 0.67 (95\% $\mathrm{CI}: 0.40-1.10)$ in comparison to the women who slept for $6 \mathrm{~h}$ per night. Inverse associations were reported predominantly in lean women. Conclusively, sleeping duration had a considerable influence on the development of breast cancer, mostly based on its effect on body melatonin levels.

Hurley et al. (2015) analysed sleep duration and the risk of specifically selected cancers in a group of women from California in a prospective cohort: the California Teachers Study. Cancer analyses focused on specific cancers, including colorectal, breast, lung, melanoma and endometrial cancers. Using average sleepers (7-9h per night) as the reference group, Hurley et al. found that long sleepers registered a statistically significant rise in the risk of all estrogen-intermediated malignancies 

$\mathrm{HR}(95 \% \mathrm{CI})=1.22$ (0.97 to 1.54), $\left(\mathrm{P}_{\text {trend }}=0.04\right)$. The authors concluded that longer sleeping durations among participants might be linked to increased risk of estrogenarbitrated types of cancers.

Gu et al. (2016) explored the connotations between sleeping durations and the risk of 18 location-specific types of malignancies using self-reported sleeping patterns of study participants from a Health and Diet Cohort Study. Females reported a reduction in the risk of developing breast cancer in participants who slept for $<5 \mathrm{~h}$ per night in comparison to participants in the reference group (7-8h/night) HR (95\% CI) $=0.84$; (0.71-0.98).

\section{Short sleep duration and risk of breast cancer}

A standard reference category of people who slept for 7 hours per night was used to calculate the odds of a short sleeper developing breast cancer. The pooled-effect OR was obtained as $\mathrm{OR}=0.92(0.88-0.96)$ based on the fixed-effects model. For studies that reported or used a different reference category, the standard reference category of 7 hours of sleep per night was used instead for uniformity, consistency and to allow comparability of the findings. The probability that a short sleeper develops breast cancer was 0.92 times higher than for the reference group. The influence of short sleep on the risk of breast cancer was statistically significant (Figure 2).

The amount of heterogeneity was $\mathrm{I}^{2}=74.40 \%$ (95\% CI $48.20-87.40$ ), suggestive of moderate to high heterogeneity among the included studies. The Q-statistic was $Q=27.36$ ( $p=0.00)$. Eggers regression revealed non-statistically significant evidence for funnel plot asymmetry ( $\mathrm{p}=0.74)$. This was supported by the funnel plot for the assessment of publication bias, which also illustrated symmetry (Figure 3). Study 7 (Hurley et al., 2015) accounted the most towards overall heterogeneity as illustrated by Figure 5 . 


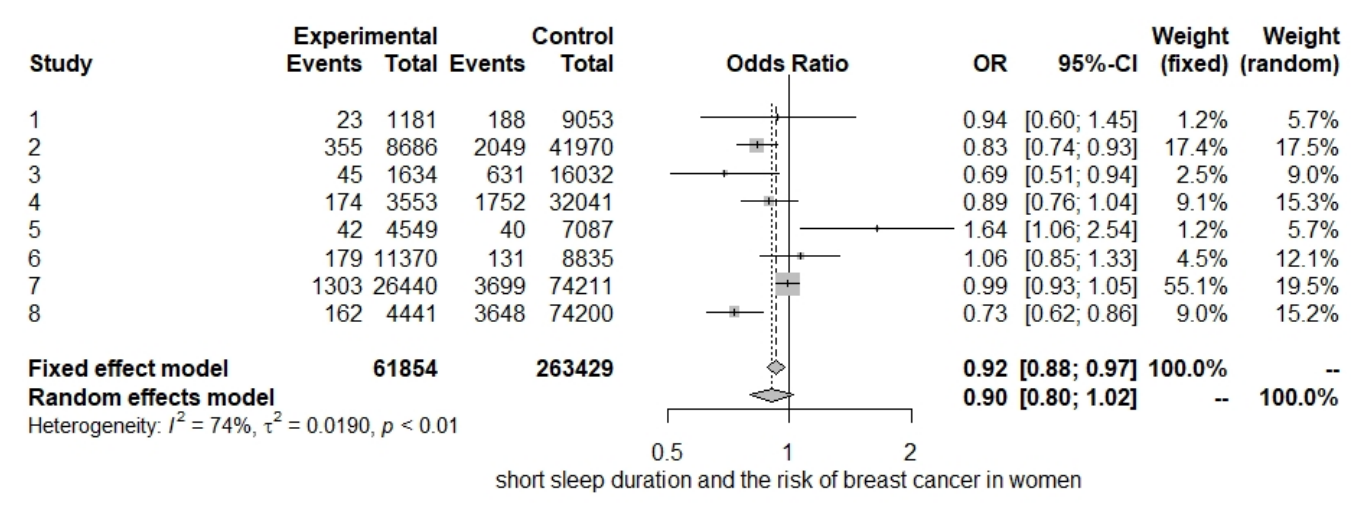

Figure 2: A Forest Plot. Point estimates and $95 \% \mathrm{Cl}$ represent all the studies encompassed in the meta-analysis. The size of the boxes mirrors the weight of the study.

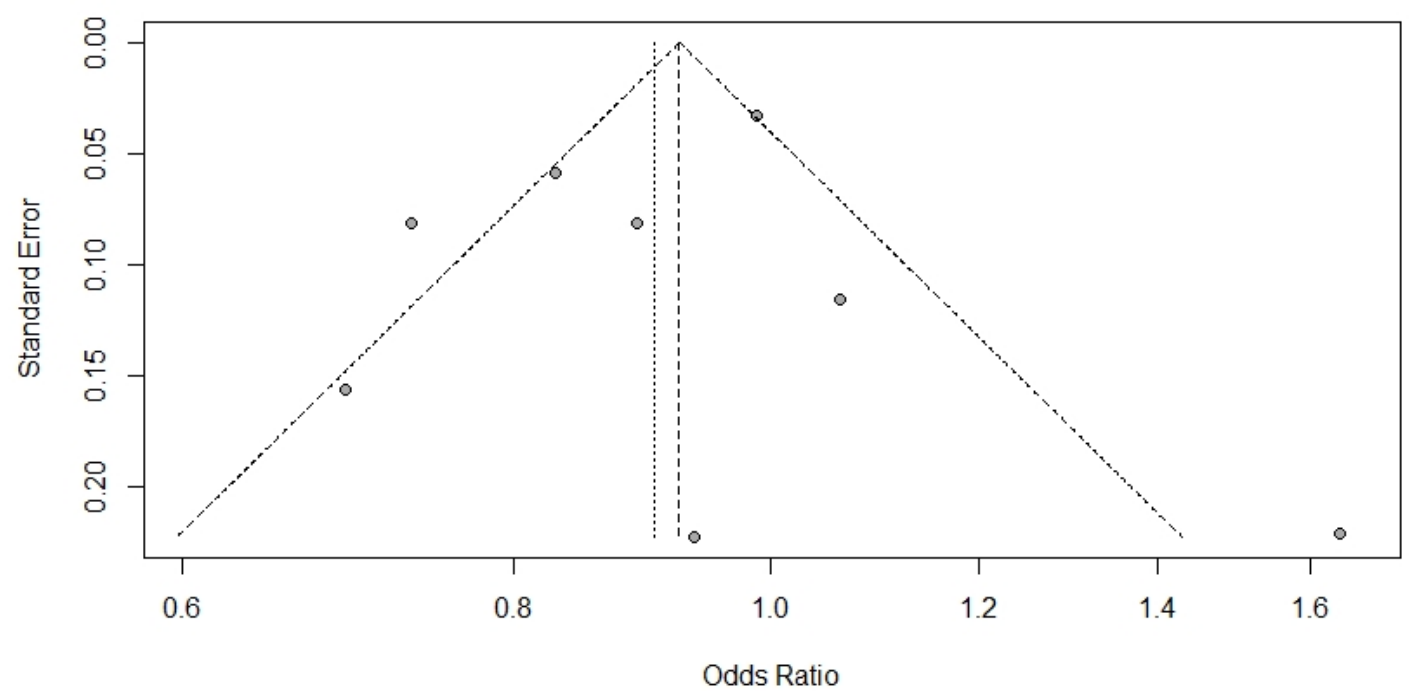

Figure 3: A Funnel Plot. This plot is symmetric where points fall on both sides of the summary effect size. These results are consistent with Eggers regression

Long sleep duration and risk of breast cancer

The pooled-effect OR (95\% CI) for the included studies was OR=0.95 (0.89-1.02) for the cohort studies included in the analysis based on the fixed-effects model. The probability that a long sleeper ( $\geq 8 \mathrm{~h}$ ) develops breast cancer was 0.95 times higher than the probability that a person in the reference group (7h) develops breast cancer. The 
influence of extended sleep on the risk of breast cancer was statistically insignificant $(\mathrm{p}=0.21)$ (Figure 4).

The amount of heterogeneity was $\mathrm{I}^{2}=3.00 \%$ (95\% CI 0.00-68.60), suggestive of a low to moderate heterogeneity among the included studies. The $Q$-statistic was $Q=7.22$ $(p=0.40)$. Eggers regression revealed non-statistically significant evidence for funnel plot asymmetry ( $\mathrm{p}=0.07$ ) as the funnel plot was symmetric (Figure 6). Study 10 (Vogtmann et al., 2013) accounted the most towards overall heterogeneity (Figure 5).

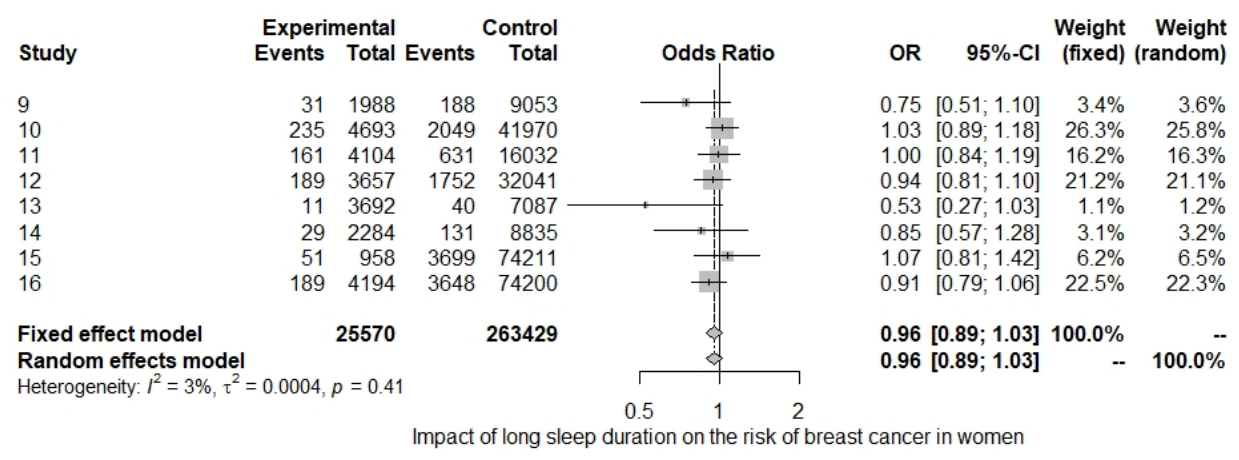

Figure 4: A Forest Plot. Summary of the effect of long sleeping duration on the risk of cancer of the breast.

Heterogeneity assessment 

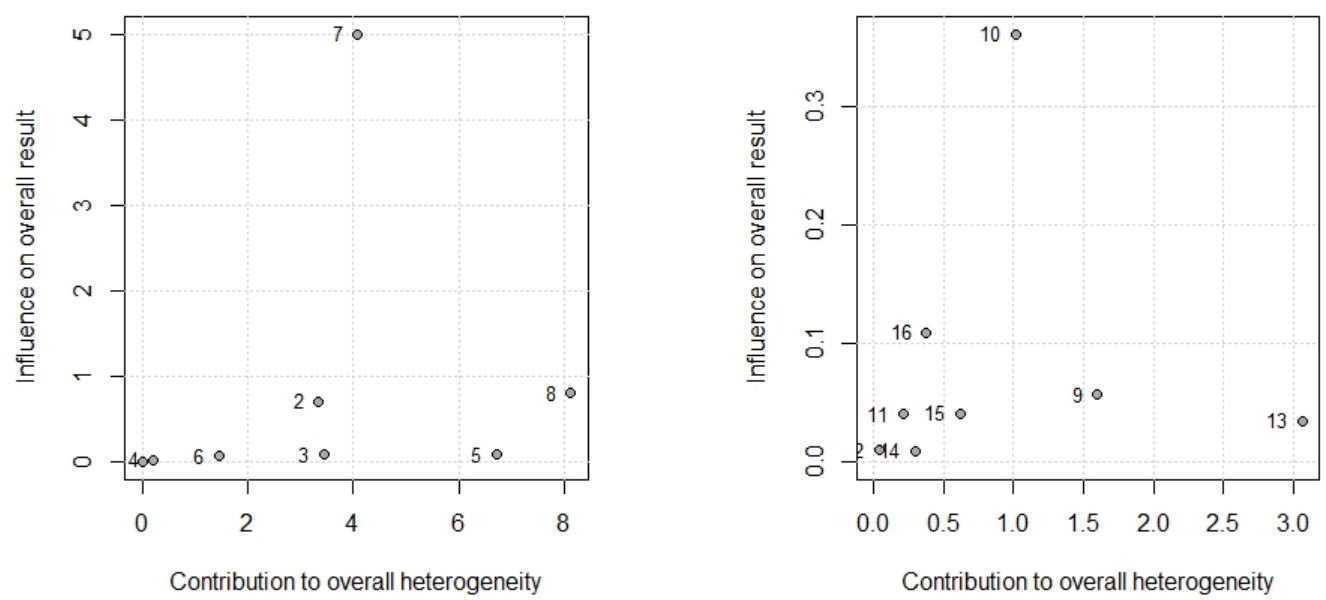

Figure 5: A Baujat Plot for the estimation of overall study heterogeneity. The plot on the left examines the heterogeneity in studies of short sleep and breast cancer, whereas the plot on the right examines the effect of extended sleep. Studies on the upper quadrant have a strong influence on heterogeneity.

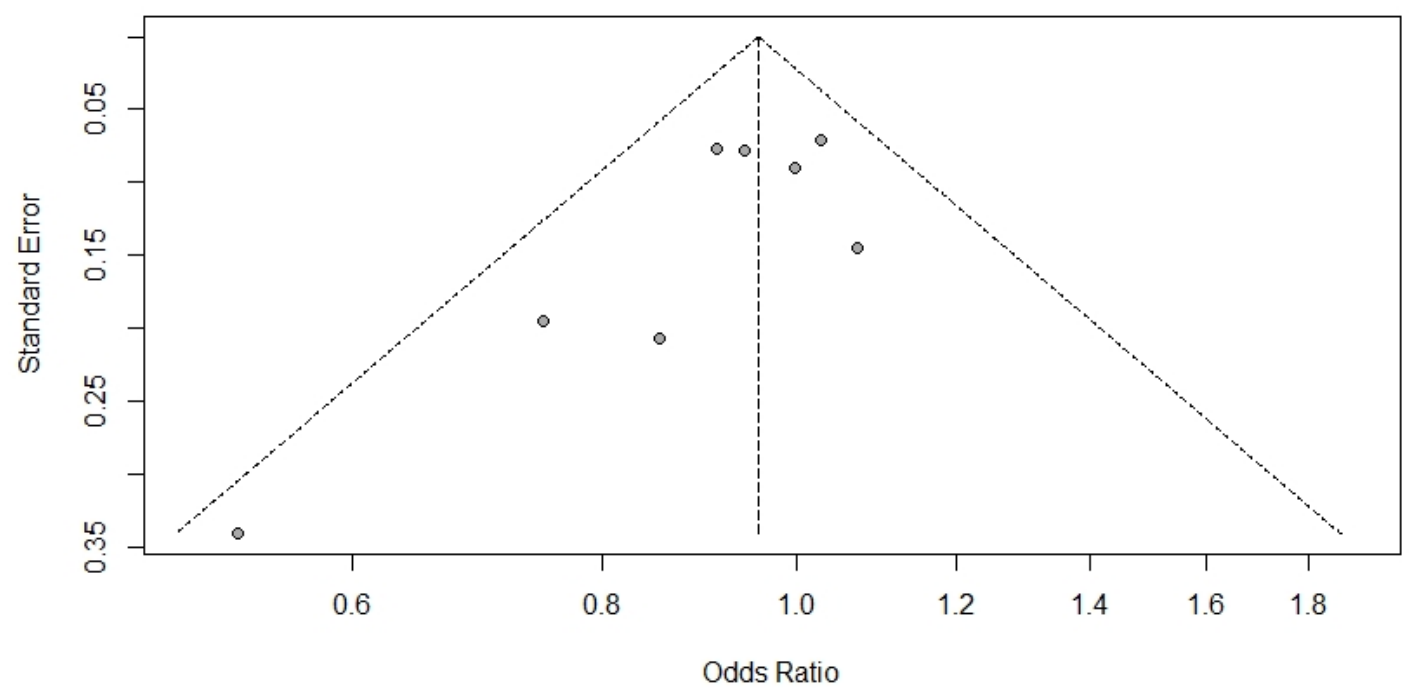

Figure 6: A Funnel Plot illustrating symmetry of studies examining the impact of long sleeping patterns on the risk of breast cancer.

\section{Discussion}

This study comprehensively reviewed literature related to the impact of both long and short categories of sleeping on the risk of developing breast cancer in females using population-based cohort studies that met the inclusion criteria. Whereas this analysis found no statistically significant links between long sleeping duration and the risk of 
breast cancer based on both fixed- and random-effects models, the study did find statistically significant evidence of influence of short sleeping patterns on the risk of breast cancer based on the fixed-effects model. However, on the other hand, the random-effects model revealed non-statistically significant evidence of an association between short sleep and cancer of the breast.

Comparing these findings (random-effects model results) to previously conducted individual researches on the same topic, consistencies were with a study that reported that sleeping durations (both short and long) had a non-significant statistical impact or association with an increase in cancer risk (Zhao et al., 2013). Besides, an analysis of prospective cohort studies by Lu et al. (2013) did not find substantial evidence of an association between the duration of sleep and an increased risk of all cancers (Lu et al., 2013).

\section{Possible explanations of associations between breast cancer and sleep}

While cancer as a disease has a multi-faceted etiology, different studies have tried to explain the link or pathways behind the relationship between breast cancer (and all cancers) and the duration of sleep. In previous studies, decreased melatonin levels have been linked to short sleeping durations; in addition, melatonin has been proposed as a suppressor of the initial phase in tumour generation, a process that inhibits propagation of cancer cells in humans (Blask, 2009; Hill et al., 2015).

Moreover, studies have also tried to explain the association between breast cancer using sex hormones (Germain, 2011). Melatonin might have a modulating effect on the production of sex hormones through its interactions with estrogen-signalling pathways using a variety of mechanisms (Alvarez-García et al., 2013).

Bovbjerg (2003) linked impairments in immune functioning in his explanation of sleep and regulation of the immune system. Sleep deficiency studies have found that changes in duration of sleep might suppress the functioning of the immune system, resulting in shifts in the production of cytokine (Chen et al., 2018). Also, circadian physiology disruptions have also been used in explaining sleep disturbances with respect to all cancers (Hill et al., 2015).

Study strengths and limitations 
This study has comprehensively used up-to-date literature on sleep and breast cancer, predominantly cohort studies to explain whether there exist associations between long and short categories of sleep and risk of breast cancer in women. The studies synthesised had considerably large sample sizes, which improved the statistical power. Moreover, the pooled effects of the studies included in the analysis were analysed using both fixed- and random-effects models, allowing comparison of the findings.

Sub-group analysis was performed separately using both short and long durations of sleep, a situation that allowed an analysis of the effect of each paying attention to breast cancer. Besides, data for the pooled effect was obtained from the primary cohort studies in which individuals were followed prospectively. The methodology employed in the evaluation of the eminence of the cohort studies encompassed in this analysis strengthens the validity of the findings of this paper.

On the other hand, this meta-analysis did not use adjusted estimates from the previously conducted studies, a situation that might have allowed effects of confounding variables, which might obscure the true associations between variables. Studies synthesised in this paper had different classifications of sleeping categories in addition to the measures of sleep being self-reported. Studies reported different measures of association (RR, OR and HRs); we, however, used the OR calculated from the estimates obtained from various studies (see Script).

\section{Conclusions}

While individuals continue to sleep less due to stress, anxiety, depression and change in lifestyle behaviours, findings from this analysis suggest non-statistically significant relations between durations of sleep and breast cancer. Future research studies should be focused on establishing the links and mechanisms suggesting relationships between sleep and breast cancer using more reliable measures of sleep durations to enhance the quality of the sleep measures obtained.

\section{List of figures}

Figure 1: PRISMA Flow Diagram for the included studies. The flow diagram indicates the number of studies included in the meta-analysis at each stage. Adapted from: Moher et al., 2009). 
Figure 2: A Forest Plot. Point estimates and 95\% CI represent all the studies encompassed in the meta-analysis. The size of the boxes mirrors the weight of the study.

Figure 3: A Funnel Plot. This plot is symmetric where points fall on both sides of the summary effect size. These results are consistent with Eggers regression

Figure 4: A Forest Plot. Summary of the effect of long sleeping duration on the risk of cancer of the breast.

Figure 5: A Baujat Plot for the estimation of overall study heterogeneity. The plot on the left examines the heterogeneity in studies of short sleep and breast cancer, whereas the plot on the right examines the effect of extended sleep. Studies on the upper quadrant have a strong influence on heterogeneity.

\section{List of tables}

Table 1: Characteristics of the included cohort studies

Table 2: Meta-analyses data and study quality assessment

\section{References}

Alvarez-García, V., A. González, C. Martínez-Campa, C. Alonso-González and S. Cos (2013), 'Melatonin modulates aromatase activity and expression in endothelial cells', Oncology Reports, 29 (5), 2058-64, doi: 10.3892/or.2013.2314

Blask, D. E. (2009), 'Melatonin, sleep disturbance and cancer risk', Sleep Medicine Reviews, 13 (4), 257-64, doi: 10.1016/j.smrv.2008.07.007

Bovbjerg, D. H. (2003), 'Circadian disruption and cancer: Sleep and immune regulation', Brain, Behavior, and Immunity, 1 (17), 48-50, doi: 10.1016/s0889-1591 (02)00066-1

Bray, F., J. Ferlay, I. Soerjomataram, R. L. Siegel, L. A. Torre and A. Jemal (2018), 'Global cancer statistics 2018: GLOBOCAN estimates of incidence and mortality worldwide for 36 cancers in 185 countries', CA: A Cancer Journal for Clinicians, 68 (6), 394-424, doi: 10.3322/caac.21492 
Chen, Y., F. Tan, L. Wei, X. Li, Z. Lyu, X. Feng, Y. Wen, L. Guo, J. He, M. Dai and N. Li (2018), 'Sleep duration and the risk of cancer: A systematic review and metaanalysis including dose-response relationship', BMC Cancer, 18 (1), 1149, doi: 10.1186/s12885-018-5025-y

Cohen, J. M., Y. T. Li, S. Wu, J. Han, A. A. Qureshi and E. Cho (2015), 'Sleep duration and sleep-disordered breathing and the risk of melanoma among US women and men', International Journal of Dermatology, 54 (11), e492-95, doi: 10.1111/ijd.12904

Egger, M., G. D. Smith, M. Schneider, C. Minder, M. Tabuso, A. Dunlop and R. Arasaradnam (1997), 'Bias in meta-analysis detected by a simple, graphical test', BMJ (Clin Res Ed), 315 (7109), 629-34, doi: 10.1136/bmj.315.7109.629

Gangwisch, J. E., S. B. Heymsfield, B. Boden-Albala, R. M. Buijs, F. Kreier, T. G. Pickering, A. G. Rundle, G. K. Zammit and D. Malaspina (2007), 'Sleep duration as a risk factor for diabetes incidence in a large US sample', Sleep, 30 (12), 1667-73, doi: 10.1093/sleep/30.12.1667

Germain, D. (2011), 'Estrogen carcinogenesis in breast cancer', Endocrinology and Metabolism Clinics of North America, 40 (3), 473-84, doi: 10.1016/j.ecl.2011.05.009

Gu, F., Q. Xiao, L. W. Chu, K. Yu, C. E. Matthews, A. W. Hsing, and N. E. Caporaso (2016), 'Sleep duration and cancer in the NIH-AARP diet and health study cohort', PLoS ONE, 11 (9), e0161561, doi: 10.1371/journal.pone.0161561

Heckman, C. J., J. D. Kloss, D. Feskanich, E. Culnan and E. S. Schernhammer (2017), 'Associations among rotating night shift work, sleep and skin cancer in Nurses' Health Study II participants', Occupational and Environmental Medicine, 74 (3), 169-75, doi: 10.1136/oemed-2016-103783

Hill, S. M., V. P. Belancio, R. T. Dauchy, S. Xiang, S. Brimer, L. Mao, A. Hauch, P. W. Lundberg, W. Summers, L. Yuan, T. Frasch and D. E. Blask (2015), 'Melatonin: An inhibitor of breast cancer', Endocrine-Related Cancer, 22 (3), R183-R204, doi: 10.1530/ERC-15-0030

Hurley, S., D. Goldberg, L. Bernstein and P. Reynolds (2015), 'Sleep duration and cancer risk in women', Cancer Causes and Control, 26 (7), 1037-45, doi: 10.1007/s10552-015-0579-3 
Irwin, M. R., M. Wang, D. Ribeiro, H. J. Cho, R. Olmstead, E. C. Breen, O. MartinezMaza and S. Cole (2008), 'Sleep loss activates cellular inflammatory signalling', Biological Psychiatry, 64 (6), 538-40, doi: 10.1016/j.biopsych.2008.05.004

Jean-Louis, G., N. J. Williams, D. Sarpong, A. Pandey, S. Youngstedt, F. Zizi and G. Ogedegbe (2014), 'Associations between inadequate sleep and obesity in the US adult population: Analysis of the national health interview survey (1977-2009)', BMC Public Health, 14 (1), 290, doi: 10.1186/1471-2458-14-290

Jiao, L., Z. Duan, H. Sangi-Haghpeykar, L. Hale, D. L. White and H. B. El-Serag (2013), 'Sleep duration and incidence of colorectal cancer in postmenopausal women', British Journal of Cancer, 108 (1), 213-21, doi: 10.1038/bjc.2012.561

Jung, K. J., C. Jeon and S. H. Jee (2016), 'Smoking effect on lung cancer: ethnic difference and smoking paradox', Epidemiology and Health, 38, e2016060, doi: 10.4178/epih.e2016060

Kakizaki, M., S. Kuriyama, T. Sone, K. Ohmori-Matsuda, A. Hozawa, N. Nakaya, S. Fukudo and I. Tsuji (2008), 'Sleep duration and the risk of breast cancer: The Ohsaki cohort study', British Journal of Cancer, 99 (9), 1502-05, doi: 10.1038/sj.bjc. 6604684

Lu, Y., N. Tian, J. Yin, Y. Shi, and Z. Huang (2013), 'Association between sleep duration and cancer risk: A meta-analysis of prospective cohort studies', PLoS ONE, 8 (9), e74723, doi: 10.1371/journal.pone.007423

Luojus, M. K., S. M. Lehto, T. Tolmunen, A. T. Erkkilä and J. Kauhanen (2014), 'Sleep duration and incidence of lung cancer in ageing men', BMC Public Health, 14 (1), 295, doi: 10.1186/1471-2458-14-295

Ma, J. and A. Jemal (2013), 'Breast cancer statistics', in Ahmad A. (ed.), Breast Cancer Metastasis and Drug Resistance: Progress and Prospects, Springer, New York, NY, pp. 1-18, doi: 10.1007/978-1-4614-5647-6_1

Markt, S. C., E. E. Flynn-Evans, U. A. Valdimarsdottir, L. G. Sigurdardottir, R. M. Tamimi, J. L. Batista, S. Haneuse, S. W. Lockley, M. Stampfer, K. M. Wilson, C. A. Czeisler, J. R. Rider and L. A. Mucci (2016), 'Sleep duration and disruption and prostate cancer risk: A 23-year. prospective study', Cancer Epidemiology Biomarkers and Prevention, 25 (2), 302-08, doi: 10.1158/1055-9965.EPI-14-1274 
Moher, D., A. Liberati, J. Tetzlaff and D. G. Altman (2009), 'Preferred reporting items for systematic reviews and meta-analyses: the PRISMA statement', Journal of Clinical Epidemiology, 62 (10), 1006-12, doi: 10.1016/j.jclinepi.2009.06.005

Pinheiro, S. P., E. S. Schernhammer, S. S Tworoger and K. B. Michels (2006), 'A prospective study on habitual duration of sleep and incidence of breast cancer in a large cohort of women', Cancer Research, 66 (10), 5521-25, doi: 10.1158/00085472.CAN-05-4652

Qian, X., L. A. Brinton, C. Schairer and C. E. Matthews (2015), 'Sleep duration and breast cancer risk in the Breast Cancer Detection Demonstration Project follow-up cohort', British Journal of Cancer, 112 (3), 567-71, doi: 10.1038/bjc.2014.600

Quintana, D. S. (2015), 'From preregistration to publication: A non-technical primer for conducting a meta-analysis to synthesise correlational data', Frontiers in Psychology, 6, 1549, doi: 10.3389/fpsyg.2015.01549

Sanchis-Gomar, F., A. Lucia, T. Yvert, A. Ruiz-Casado, H. Pareja-Galeano, A. SantosLozano, C. Fiuza-Luces, N. Garatachea, G. Lippi, C. Bouchard and N. A. Berger (2015), 'Physical inactivity and low fitness deserve more attention to alter cancer risk and prognosis', Cancer Prevention Research, 8 (2), 105-10, doi: 10.1158/19406207.CAPR-14-0320

Schwarzer, G., J. R. Carpenter and G. Rücker (2015). Meta-analysis with R, 4784 vols, Cham: Springer, doi: 10.1007/978-3-319-21416-0

Shamseer, L., D. Moher, M. Clarke, D. Ghersi, A. Liberati, M. Petticrew, P. Shekelle, A. Stewart, D. Altman, A. Booth, A. W. Chan, S. Chang, T. Clifford, K. Dickersin, M. Egger, P.C. Gøtzsche, J. Grimshaw, T. Groves, M. Helfand, J. Higgins, T. Lasserson, J. Lau, K. Lohr, J. McGowan, C. Mulrow, M. Norton, M. Page, M. Sampson, H. Schünemann, I. Simera, W. Summerskill, J. Tetzlaff, T. Trikalinos, D. Tovey, L. Turner and E. Whitlock (2015), 'Preferred reporting items for systematic review and meta-analysis protocols (prisma-p) 2015: Elaboration and explanation', BMJ, 349, doi: 10.1136/bmj.g7647

Stang, A. (2010), 'Critical evaluation of the Newcastle-Ottawa scale for the assessment of the quality of nonrandomised studies in meta-analyses', European Journal of Epidemiology, 25 (9), 603-05, doi: 10.1007/s10654-010-9491-z 
Stevens, R. G. (2005), 'Circadian disruption and breast cancer: From melatonin to clock genes', Epidemiology, 16 (2), 254-58, doi: 10.1097/01.ede.0000152525.21924.54

Topazian, H., M. Cira, S. M. Dawsey, J. Kibachio, L. Kocholla, M. Wangai, J. Welch, M. J. Williams, K. Duncan and A. Galassi (2016), 'Joining forces to overcome cancer: The Kenya cancer research and control stakeholder program', Journal of Cancer Policy, 7, 36-41, doi: 10.1016/j.jcpo.2015.12.001

Verkasalo, P. K., K. Lillberg, R. G. Stevens, C. Hublin, M. Partinen, M. Koskenvuo and J. Kaprio (2005), 'Sleep duration and breast cancer: A prospective cohort study', Cancer Research, 65 (20), 9595-600, doi: 10.1158/0008-5472.CAN-05-2138

Vogtmann, E., E. B. Levitan, L. Hale, J. M. Shikany, N. A. Shah, Y. Endeshaw, J. E. Manson and R. T. Chlebowski (2013), 'Association between sleep and breast cancer incidence among postmenopausal women in the women's health initiative', Sleep, 36 (10), 1437-44, doi: 10.5665/sleep.3032

Wang, P., F. M. Ren, Y. Lin, F. X. Su, W. H. Jia, X. F. Su, L. Y. Tang and Z. F. Ren (2015), 'Night-shift work, sleep duration, daytime napping, and breast cancer risk', Sleep Medicine, 16 (4), 462-68, doi: 10.1016/j.sleep.2014.11.017

Wang, X., W. Cheng, J. Li and J. Zhu (2016), 'A meta-analysis of alcohol consumption and thyroid cancer risk', Oncotarget, 7 (34), 55912, doi: 10.18632/oncotarget.10352

Wu, A. H., R. Wang, W. P. Koh, F. Z. Stanczyk, H. P. Lee and M. C. Yu (2008), 'Sleep duration, melatonin and breast cancer among Chinese women in Singapore', Carcinogenesis, 29 (6), 1244-48, doi: 10.1093/carcin/bgn100

Yip, C. H., R. A. Smith, B. O. Anderson, A. B. Miller, D. B. Thomas, E. S. Ang, R. S. Caffarella, M. Corbex, G. L. Kreps and A. McTiernan (2008), 'Guideline implementation for breast healthcare in low- and middle-income countries: Early detection resource allocation', in Cancer, 113 (S8), 2244-56, doi: 10.1002/cncr.23842

Zhao, H., J. Y. Yin, W. S. Yang, Q. Qin, T. Li, Y. Shi, Q. Deng, S. Wei, L. Liu, X. Wang and S. F. Nie (2013), 'Sleep duration and cancer risk: A systematic review and metaanalysis of prospective studies', Asian Pacific Journal of Cancer Prevention, 14 (12), 7509-15, doi: 10.7314/APJCP.2013.14.12.7509 
Reinvention: an International Journal of Undergraduate Research 13:1 (2020)

To cite this paper please use the following details: Okutse, A.O (2020), "The Impact of Sleeping Duration on the Risk of Breast Cancer: A systematic review and metaanalysis of population-based cohort studies', Reinvention: an International Journal of Undergraduate Research, Volume 13, Issue 1, https://reinventionjournal.org/article/view/530. Date accessed [insert date]. If you cite this article or use it in any teaching or other related activities please let us know by emailing us at Reinventionjournal@warwick.ac.uk. 